\title{
Helicobacter pylori is killed by nitrite under acidic conditions
}

\author{
R S Dykhuizen, A Fraser, H McKenzie, M Golden, C Leifert, N Benjamin
}

\begin{abstract}
Background-Due to the expression of urease, Helicobacter pylori is able to establish itself in the human stomach under acidic conditions. A novel host defence mechanism was recently proposed, suggesting that the formation of salivary nitrite in symbiosis with facultative anaerobic bacteria in the oropharynx, is aimed at enhancing the antimicrobial activity of gastric juice.

Aims-To investigate whether the addition of nitrite in physiological concentrations influences the resistance of $H$ pylori to acid.

Methods-H pylori cultured from fresh gastric biopsy specimens was exposed for 30 minutes to normal saline and to $\mathrm{HCl} / \mathrm{KCl}$ buffer $(0.2 \mathrm{M})$ at $\mathrm{pH} 2$ with urea (5 $\mathrm{mM}$ ) added. The influence of potassium nitrite $(50-1000 \mu \mathrm{mol} / 1)$ on bacterial survival was determined.

Results-Addition of nitrite (1 $\mathrm{mM})$ to acidic solutions ( plete kill of $H$ pylori within 30 minutes exposure time whereas acid alone allowed the organism to survive $(p<0.001)$. The antimicrobial effect of nitrite at $\mathrm{pH} 2$ against $H$ pylori was dose dependent and complete kill of organisms occurred at concentrations $\geqslant 500 \mu \mathrm{mol} / 1$.

Conclusion-Acidified nitrite has antibacterial activity against $H$ pylori. This should prompt further research into the effect of salivary nitrite on the survival of $H$ pylori in the human stomach.

(Gut 1998;42:334-337)
\end{abstract}

Keywords: nitrite; Helicobacter pylori; acidic conditions

Gastroenterology,

Aberdeen Royal

Infirmary NHS Trust

A Fraser

Department of Medical Microbiology,

University of Aberdeen H McKenzie

Soil Science Institute, University of Aberdeen C Leifert

Department of Clinical Pharmacology, St

Bartholomew's and the Royal London Hospital School of Medicine and Dentistry

$\mathrm{N}$ Benjamin

Correspondence to: Dr Dykhuizen.

Accepted for publication 5 September 1997

Helicobacter pylori is the commonest bacterial pathogen worldwide and more than half of the world's population of 40 years and over are colonised. ${ }^{1}$ It causes chronic active gastritis and is associated with duodenal and gastric ulcer, and gastric malignancy. ${ }^{23}$

The majority of bacterial pathogens ingested never give rise to colonisation of the gastrointestinal tract because of the gastric acid barrier. ${ }^{4} \mathrm{H}$ pylori, however, synthesises a urease enzyme which creates an alkaline environment to protect the organism from the bactericidal effect of acid. ${ }^{56}$

Recent work from our laboratories suggested a novel host defence mechanism in the mammalian upper gastrointestinal tract. We showed the generation of salivary nitrite in the mouth through a symbiotic relationship with facultative anaerobic bacteria on the tongue surface after ingestion of dietary nitrate. ${ }^{7-10}$ Addition of nitrite to acidic solutions in vitro achieves killing of human gut pathogens, whereas acid alone allows growth to continue. ${ }^{1112}$ We suggested that swallowing saliva rich in nitrite after a meal high in nitrate may enhance host defence against ingested pathogens.

In the present paper we report the antimicrobial effect of acidified nitrite on $H$ pylori in vitro. Survival of organisms was studied after exposure to test solutions with acid alone, acid plus urea, and acid plus urea and nitrite. The dose dependency of the antibacterial action of nitrite at $\mathrm{pH} 2$ has been determined.

\section{Methods}

PREPARATION OF THE INOCULATE

$H$ pylori, isolated from human gastric biopsy specimens, was cultured on horse blood agar plates incubated at $37^{\circ} \mathrm{C}$ in an atmosphere of $10 \% \mathrm{CO}_{2}, 5 \%$ oxygen, and $85 \%$ nitrogen ("campygas"). After three days' incubation, the bacteria were harvested and suspended in normal saline at $\mathrm{pH} 7$ to give a final concentration of approximately $10^{9}$ cells $/ \mathrm{ml}$ (turbidity = McFarland's no 6).

EFFECT OF EXPOSURE OF H PYLORI TO ACID, UREA, AND NITRITE

Inoculate $(1 \mathrm{ml})$ was added to $4.5 \mathrm{ml}$ of $0.2 \mathrm{M}$ $\mathrm{HCl} / \mathrm{KCl}$ buffer at $\mathrm{pH} 2$ with or without urea $(5 \mathrm{mM})$ in the solution. Immediately thereafter, normal saline $(1 \mathrm{ml})$ or potassium nitrite $(1$ $\mathrm{ml}$ ) to reach a final concentration of $1 \mathrm{mmol} / \mathrm{l}$ was added in universal containers. As a control, the experiment was repeated with $4.5 \mathrm{ml}$ normal saline at $\mathrm{pH} 7$ instead of $0.2 \mathrm{M}$ $\mathrm{HCl} / \mathrm{KCl}$ buffer.

The samples were incubated at $37^{\circ} \mathrm{C}$. After
EFFECT OF NITRITE ON $H$ PYLORI AT $\mathrm{pH} 2$ Inoculate $(1 \mathrm{ml})$ was added to $4.5 \mathrm{ml}$ of $0.2 \mathrm{M}$ $\mathrm{HCl} / \mathrm{KCl}$ buffer at $\mathrm{pH} 2$ with $5 \mathrm{mM}$ urea in the solution. Immediately thereafter, potassium nitrite solution $(1 \mathrm{ml})$ was added to reach final concentrations of $0,50,100,200,500$, and 
Table 1 Survival of H pylori (log cfu/ml (SD)) after exposure to acid ( $p H 2)$, urea (5 $\mathrm{mmol} / \mathrm{l})$, and potassium nitrite $(1 \mathrm{mmol} / \mathrm{l})$

\begin{tabular}{lll}
\hline & Nitrite absent & Nitrite present \\
\hline $\begin{array}{l}\text { Control }(\mathrm{pH} 7) \\
\begin{array}{l}0.2 \mathrm{M} \mathrm{HCl} / \mathrm{KCl}(\mathrm{pH} 2) \text { plus } \\
\text { urea }(5 \mathrm{mmol} / \mathrm{l})\end{array}\end{array}$ & $6.14(0.98)(\mathrm{n}=5)$ & $6.32(1.62)(\mathrm{n}=4)$ \\
$\begin{array}{l}0.2 \mathrm{M} \mathrm{HCl} / \mathrm{KCl}(\mathrm{pH} 2) \text { without } \\
\text { urea }\end{array}$ & $0 \dagger(\mathrm{n}=5)$ & $0 \dagger(\mathrm{n}=5)$ \\
\end{tabular}

$\star \star \star \mathrm{p}<0.001$ versus $0.2 \mathrm{M} \mathrm{HCl} / \mathrm{KCl}(\mathrm{pH} 2)$ plus urea with $1 \mathrm{mmol} / 1$ nitrite.

$\dagger$ No detectable survival.

$1000 \mu \mathrm{mol} / 1$. As a control, the experiment was repeated with $4.5 \mathrm{ml}$ normal saline at $\mathrm{pH} 7$ instead of $0.2 \mathrm{M} \mathrm{HCl} / \mathrm{KCl}$ buffer at $\mathrm{pH} 2$.

The containers were incubated at $37^{\circ} \mathrm{C}$. After 30 minutes, samples of each of the containers were taken and diluted with normal saline in serial 10 -fold dilutions for $\mathrm{cfu}$ determination. The diluted suspensions were inoculated onto horse blood agar plates and incubated in an anaerobic incubator with 5\% $\mathrm{CO}_{2}$ for up to five days. Colony counts per plate were calculated as: number of colonies $\times$ [1/dilution] $\times[1 / 0.01]$ per $\mathrm{ml}$. The lower limit of detection was $10^{2}$ organisms $/ \mathrm{ml}$.

The $\mathrm{pH}$ in the universal containers was measured with a glass $\mathrm{pH}$ electrode before and after each 30 minute incubation of $H$ pylori in acidified nitrite. The experiments were carried out in triplicate.

\section{Results}

Table 1 shows the effects of exposure of $H$ pylori to acid, urea, and nitrite. The control experiments showed some $5 \times 10^{6} \mathrm{cfu} / \mathrm{ml}$ after 30 minutes exposure at $\mathrm{pH} 7$ in the universal containers; a similar survival rate was observed when $1 \mathrm{mM}$ potassium nitrite was present. The organisms were also able to survive, although in smaller numbers, after exposure to $\mathrm{pH} 2$ in the presence of urea. However, the addition of $1 \mathrm{mM}$ potassium nitrite at $\mathrm{pH} 2$ plus urea resulted in complete kill $(\mathrm{p}<0.001)$. Without urea, $H$ pylor $i$ was unable to survive exposure at $\mathrm{pH} 2$ even in the absence of nitrite.

Figure 1 shows that the antimicrobial effect of nitrite is dose dependent. Increased kill was seen after addition of 0.05 and $0.1 \mathrm{mM}$ of nitrite in all three experiments. Although the same isolate was used, the inoculum of the first series seemed markedly more sensitive to the mechanism than those in the other two series. No survival was detected in the first series at concentrations $\geqslant 0.2 \mathrm{mmol} / \mathrm{l}$, and in the other two series at $\geqslant 0.5 \mathrm{mmol} / 1$. The difference in sensitivity of the inoculates is most likely due to differences in viability which was also apparent when the inoculates were exposed to acid alone for 30 minutes. Whereas $1 \times 10^{6} \mathrm{cfu} / \mathrm{ml}$ were recovered after inoculum 1 had been exposed to normal saline at $\mathrm{pH} 7$, only $3 \times 10^{4} \mathrm{cfu} / \mathrm{ml}$ survived after exposure to $\mathrm{HCl} / \mathrm{KCl}$ buffer at $\mathrm{pH} 2$, a killing of $97 \%$ of organisms due to acid alone. These figures were $3 \times 10^{5}$ at $\mathrm{pH} 7$ versus $1 \times 10^{5}$ at $\mathrm{pH} 2$ for the second, and $1 \times 10^{6}$ at $\mathrm{pH} 7$ versus $4 \times 10^{5}$ at $\mathrm{pH} 2$ for the third inoculum, representing killings of only $60-70 \%$ of organisms due to the addition of acid.

The $\mathrm{pH}$ was 2 in all universal containers at the start of exposure. A rise in $\mathrm{pH}$ was observed

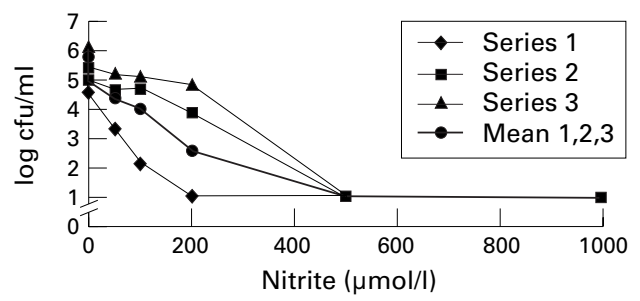

Figure 1 Antibacterial activity of nitrite against $H$ pylori at pH 2 after 30 minutes' exposure. Experiments were carried out in triplicate (series 1,2, and 3). No survival was detected at concentrations of nitrite $\geqslant 500 \mu \mathrm{mol} / \mathrm{l}$.

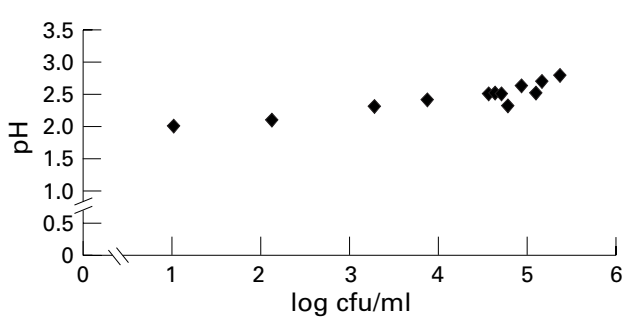

Figure 2 pH in universal containers at the end of the experiment versus number of surviving $H$ pylori (starting $p H=2$ in all experiments).

at the end of the exposure time in those containers where survival of $H$ pylori was observed. The $\mathrm{pH}$ at the end of the experiments in relation to the number of surviving organisms is plotted in fig 2 .

\section{Discussion}

The experiment, summarised in table 1, showed good survival at $\mathrm{pH} 7$. No antibacterial effect of the addition of $1 \mathrm{mM}$ potassium nitrite was observed at this $\mathrm{pH}$. H pylori were killed at $\mathrm{pH} 2$ unless urea was present in the solution. The hydrolysis of urea to ammonia and bicarbonate mediated by bacterial urease, neutralises hydrogen ions penetrating the cell wall ${ }^{6}$ :

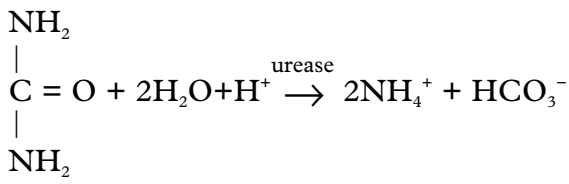

However, even in the presence of urea, the organism seemed to be unable to survive when $1 \mathrm{mM}$ of nitrite was added to the medium. Figure 1 shows the (negative) dose dependent relationship between nitrite and the number of surviving micro-organisms at $\mathrm{pH} 2$.

Acidification of nitrite caused generation of reactive intermediates of nitrogen that have cytotoxic properties:

$$
\begin{array}{rccc}
\mathrm{NO}_{2}{ }^{-}+\mathrm{H}^{+} & & \Leftrightarrow & \mathrm{HNO}_{2} \\
2 \mathrm{HNO}_{2} & \mathrm{pK}_{\mathrm{a}}=3.42 & \\
\mathrm{~N}_{2} \mathrm{O}_{3} & & \Leftrightarrow & \mathrm{H}_{2} \mathrm{O}+\mathrm{N}_{2} \mathrm{O}_{3} \\
& \Leftrightarrow & \mathrm{NO} \cdot+\mathrm{NO}_{2} .
\end{array}
$$

Nitric oxide inhibits respiratory chain enzymes through inactivation of iron-sulphur complexes, ${ }^{13}$ and disrupts DNA replication by inhibiting ribonucleotide reductase. ${ }^{14}$ Its toxicity has been shown for a rapidly expanding list of micro-organisms ${ }^{15}$ as well as for tumour cells. ${ }^{16}$ However, experiments with NO donor compounds have shown little antibacterial activity of NO itself, ${ }^{17}$ and its toxic effects are more likely to be accomplished via the 
formation of peroxynitrite in the presence of superoxide, ${ }^{18}$ the oxygen dependent generation of the nitrogen dioxide radical when nitric oxide concentrations are high, ${ }^{19}$ and/or still uncharacterised nitrogen species. ${ }^{20}$ It seems most likely that the antibacterial activity of acidified nitrite is due to an additive contribution of reactive intermediates of nitrogen. ${ }^{21}$

In addition to the uncertainty about the identity of the reactive intermediate(s) of nitrogen responsible for the antimicrobial activity observed, the data in this paper leave room for the interpretation that the kill of $H$ pylori by acidified nitrite is not due to antibacterial action per se but is merely a result of inhibition of the urease enzyme. The demonstration of antimicrobial activity of acidified nitrite against other gut pathogens that are urease negative, ${ }^{12}$ and against the yeast Candida albicans, ${ }^{11}$ offers support for a true antibacterial action, but clearly further research is needed into the causal relationship between acidified nitrite and death of micro-organisms.

The selection of the experimental range of nitrite concentrations in this paper is based on values of salivary nitrite as they have been reported for the past 30 years. ${ }^{22}$ The concentration of nitrite in human saliva varies from 0.05 to $1 \mathrm{mmol} / \mathrm{l}$, depending on dietary intake of nitrate. Gastric nitrite concentrations are significantly lower than salivary concentrations because of the formation of nitrous acid $\left(\mathrm{HNO}_{2}\right)$, which reacts to generate other oxides of nitrogen as indicated above. Nitric oxide and nitrogen dioxide escape into the gaseous phase. Lundberg et al showed the production of nitric oxide in gastric headspace gas after a nitrate meal in human volunteers. ${ }^{23}$ In this journal, we recently reported a rise in gastric nitrite concentrations and nitric oxide production after a nitrate drink (2 $\mathrm{mmol}$ ) in human volunteers. ${ }^{24}$ Salivary nitrite concentrations increased from about $50 \mu \mathrm{mol} / 1$ to $800 \mu \mathrm{mol} / 1$ and gastric nitrite concentrations from less than $20 \mu \mathrm{mol} / 1$ to more than 100 $\mu \mathrm{mol} / \mathrm{l}$. We also showed a rise in gastric headspace gas nitric oxide concentration from less than 20 parts per million to a maximum of 291 parts per million. The increase in gastric nitric oxide production was sustained for more than two hours after nitrate ingestion. The depletion of nitrite due to the formation of other oxides of nitrogen is the main cause of the discrepancy between salivary and gastric nitrite concentrations, which cannot be explained by dilution of saliva with gastric contents alone. The data presented in this paper show no effect of nitrite at neutral $\mathrm{pH}$ on the survival of $H$ pylori. This implies that reactive oxides of nitrogen rather than nitrite itself were responsible for the antibacterial action of acidified nitrite. The generation of these reactive compounds in the stomach is dependent on the continuous supply of nitrite by the swallowing of saliva.

Snepar et $a l^{25}$ showed that treatment with cimetidine has a significant effect in raising gastric microbial titres. The number of organisms present in gastric secretions correlates directly with the gastric $\mathrm{pH}$. A similar increase was observed by Verdu $e t a l^{26}$ in the concentration of nitrate reducing bacteria after treatment with omeprazole. Although the authors could not show a concurrent rise in gastric nitrite concentrations, it is possible that overgrowth of these bacteria could have a role in the reduction of $H$ pylori after acid inhibitory treatment.

Foods which contain a high concentration of nitrate are green leafy vegetables. Since increasing the dietary intake of nitrate will result in increased salivary nitrite, ingestion of foods rich in nitrate may protect against colonisation of the stomach by $H$ pylori. There is no epidemiological evidence that people with a high nitrate intake might have a reduced prevalence of the organism. On the contrary, transmission of the infection has been related to consumption of uncooked vegetables, ${ }^{27}$ and the infection is acquired earlier with a high percentage of the adult population infected in developing countries where nitrate intake is expected to be relatively high. ${ }^{1}$ However, no investigations have been conducted to investigate the relation between dietary nitrate intake and survival of $H$ pylori.

Whether or not the antimicrobial mechanism of acidified nitrite against $H$ pylori is active in vivo, its demonstration in vitro should prompt further study of the role of the oxides of nitrogen in this infection.

1 Megraud F, Brassens-Rabbe MP, Denis F, Belbouri A, Hoa $\mathrm{DQ}$. Seroepidemiology of Campylobacter pylori infection in various populations. F Clin Microbiol 1989;27:1870-3.

2 Graham DY, Lew GM, Klein PD, et al. Effect of treatment of Helicobacter pylori infection on the long-term recurrence of gastric or duodenal ulcer-a randomized controlled study. Ann Intern Med 1992;116:705-8.

3 Parsonnet J. Helicobacter pylori and gastric cancer. Gastroenterol Clin North Am 1993;22:89-104.

4 Giannella RA, Broitman SA, Zamcheck M. Gastric barrier to ingested microorganisms in man: studies in vivo and in vitro. Gut 1972;13:251-7.

5 Langenberg ML, Tytgat GMJ, Schipper ME, Rietstra PJG, Zanen C. Campylobacter-like organisms in the stomach of patients and healthy individuals. Lancet 1984;i:1348-9.

6 Marshall BJ, Barrett LJ, Prakash C, McCallum RW, Guerrant RL. Urea protects Helicobacter (Campylobacter pylori) from the bactericidal effect of acid. Gastroenterology
1990;99:697-702. Duncan C, Dougal

, Johnston $\mathrm{P}$, et al. Chemical veric oxide in the mouth from the enterosali-

vary circulation of dietary nitrate. Nat Med 1995;1:546-51. Duncan C, Benjamin N, Li H, Kelly D, Leifert C.
Population dynamics of nitrite producing bacteria on Population dynamics of nitrite producing b
animal tongues. Physiol Zoology 1995;68:153-5.

9 Leifert C, Duncan C, Li H, Kelly D, Benjamin N. Nitrite production by bacteria on animal tongues; a resistance mechanism against food borne diseases. Physiol Zoology 1995;68:151-3

10 Dougall H, Smith L, Duncan C, Benjamin N. The effect of a broad spectrum antibiotic on salivary nitrite concentrations: an important mechanism of adverse reactions? Br f Clin Pharmacol 1995;39:460-2.

11 Benjamin N, O'Driscoll F, Dougall $\mathrm{H}$, et al. Stomach NO synthesis. Nature 1994;368:502.

12 Dykhuizen RS, Frazer R, Duncan C, Smith CC, Benjamin $\mathrm{N}$, Leifert C. Antimicrobial activity of acidified nitrite on gut pathogens: the importance of dietary nitrate in host gut pathogens. the importance of dietary nitrate in host

13 Granger DL, Lehninger AL. Sites of inhibition of mitochondrial electron transport in macrophage-injured neoplastic drial electron transport in macroph
cells. 7 Cell Biol 1982;95:527-35.

14 Nakaki T, Nakayama M, Kato R. Inhibition by nitric oxide and nitric-oxide-producing vasodilators of DNA synthesis in vascular smooth muscle cells. Eur F Pharmacol 1990;189: $347-53$

15 De Groote MA, Fang FC. NO inhibition: antimicrobial properties of nitric oxide. Clin Infect Dis 1995;21(suppl 2):S162-5.

16 Nathan C. Nitric oxide as a secretary product of mammalian cells. FASEB f 1992;6:3051-64.

17 DeGroote MA, Granger D, Xu Y, Campbell G, Prince, Fang FC. Genetic and redox determinants of nitric oxide cytotoxicity in a Salmonella typhimurium model. Proc Natl Acad Sci 1995;92:6399-403.

18 Zhu L, Gunn C, Beckmann JS. Bactericidal activity of peroxynitrite. Arch Biochem Biophys 1992;298:452-7.

19 Brunelli L, Crow JP, Beckmann JS. The comparative toxicity of nitric oxide and peroxynitrite to Escherichia coli. Arch Biochem Biophys 1995;303:327-34. 
20 Wink DA, Darbyshire JF, Nims RW, Saavedra JE, Ford PC. Reactions of the bioregulatory agent nitric oxide in oxygenated aequous media: determination of the kinetics for oxidation and nitrosation by intermediates generated in the $\mathrm{NO} / \mathrm{O}_{2}$ reaction. Chem Res Toxicol 1993;6:23-7.

21 Klebanoff SJ. Reactive nitrogen intermediates and antimicrobial activity: role of nitrite. Free Radical Biology 1993;14 351-60.

22 Ishiwata $\mathrm{H}$, Tanimura A, Ishidate $M$. Nitrite and nitrate concentrations in human saliva collected from salivary ducts. F Food Hyg Soc Fapan 1975;16:89-92.

23 Lundberg JON, Weitzberg E, Lundberg JM, et al. Intragasexpelled air. Gut 1994;35:1543-6
24 McKnight GM, Smith LM, Drummond RS, Duncan CW, Golden M, Benjamin N. Chemical synthesis of nitric oxide in the stomach from dietary nitrate in humans. Gut 1997;40:211-14.

25 Snepar R, Poporad GA, Romano R, Kobasa WD, Kaye D. Effect of cimetidine and antacid on gastric microbial flora. Infect Immun 1982;36:518-24.

26 Verdu E, Viani F, Armstrong D, et al. Effect of omeprazole on intragastric bacterial counts, nitrates, nitrites, and N-nitroso compounds. Gut 1994;35:455-60

27 Hopkins RJ, Vial PA, Ferreccio C, et al. Seroprevalence of Helicobacter pylori in Chile: vegetables may serve as one route of transmission. F Infect Dis 1993;168:222-6. 